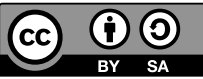

DOI: https://doi.org/10.4312/keria.22.1.5-11

\title{
Brane Senegačnik
}

\section{Skica za portret}

Caietano Gantar nonagenario gratissimo animo

»Tu bela črta je in tu je črna./ A dobro vidim, kar je še vmes.« Tako se začenja sonet Belo in črno, ki ga je pesnik Alojz Gradnik posvetil grafični umetnosti svojega občudovalca in ustvarjalnega sopotnika Božidarja Jakca. Nazorne, čisto preproste besede $\mathrm{z}$ nekakšno težo prvobitnosti $\mathrm{v}$ sebi kakor odsevajo asketske, skorajde skope linije podobe, ki so jo odtisnile na papir ureznine lesoreza. Takó umetnost zrcali umetnost: s pomenom in obliko. In pesem gre naprej in razkriva nevidno, ki ga zarisujejo vidne črte: tam so vonjave in glasovi, ves bivanjski in naravni kozmos, ki se na koncu strne, a tudi poskrivnosti v otipljivo človeško podobo grafika samega. Ta pesem pa je tudi pripoved o tem, kako veliko lahko umetnost občutliivemu gledalcu pove $\mathrm{z}$ malo potezami, če so prave. Morda pa lahko tudi sicer drobni, nepomembni pripetljaji in za javnost nevidna srečanja včasih bolj približajo človeško podobo kake osebnosti kot izčrpno, z vestno sistematiko izdelane predstavitve, tudi če so zabeleženi brez vsakih umetniških pretenzij in iluzij. V upanju, da bi lahko bilo tako, sem ob devetdesetletnici akademika profesorja Kajetana Gantarja nanizal nekaj bolj ko ne naključnih vtisov in spominov, ki pa so, četudi nebistveni in še več, povsem prigodnega značaja, vendarle tako živi, da se mi sploh ni treba potruditi, da bi jih priklical. Ker so tu in zdaj. Če pa mi ne bo uspelo in se motim, se bom tolažil in zagovarjal z Ovidijem: ut desint vires, tamen est laudanda voluntas (Pont. 3.4.79).

Ko sem postal akademski učenec profesorja Gantarja, so bili drugačni časi, v marsičem zelo drugačni. Mlajši ljudje si najbrž le težko zamislijo življenje brez interneta, saj si ga tudi sam komajda, čeprav sem polovico življenja preživel v svetu, ki še ni bil prepleten s tem informacijskim ožiljem. Znanje je bilo zato veliko teže dostopno, $v$ tedanji državi so njegovo dostopnost še dodatno zmanjševale ekonomske in politične razmere; $v$ splošnem ga je bilo med ljudmi zagotovo mnogo manj, a po drugi strani ni bilo tako instantno, namenjeno hitri 
uporabi ali celo razkazovanju. Črpali smo ga iz knjig, revij in fotokopij: svet vedenja in duha, svet kulturne odličnosti je bil za nas tako predvsem svet knjig. Kdor pa bere knjige antične literature v slovenščini, ne more mimo imena Kajetan Gantar. Ob vpisu na fakulteto je bil zato Kajetan Gantar tako kot Anton Sovre zame pravcata legenda (ta beseda se tedaj ni uporabljala za splošni prijateljski vzdevek, kot se v nekaterih oblikah sodobnega urbanega slenga, seveda če ni v nagli premeni te najbolj dinamične zvrsti tudi to že izginilo iz rabe): torej osebnost iz visokega, oddaljenega, nedostopnega sveta odličnosti, zame predvsem sveta poezije, tiste najvišje: Sofoklove, Ajshilove, Heziodove, Ovidijeve ... Tako je bilo že takrat, čeprav je marsikateri, tudi temeljni prevod (npr. Sofoklovega Ajanta in Ojdipa v Kolonu, spisa o Vzvišenem) nastal šele pozneje, saj je profesor ves čas brez predaha prevajal in še zmeraj prevaja z nezmanjšano intenzivnostjo. A tedaj se je začela legendarna postava pretapljati v realnost, lepo, a zahtevno: profesorja seveda nismo le poslušali na predavanjih, ampak smo se z njm srečevali tudi na seminarju in v njegovem kabinetu pri izpitih. In mislim, da je bil zahteven učitelj. To se ni kazalo v kakšnih visoko postavljenih, rigidnih zunanjih zahtevah, temveč bolj v vprašanjih in podvprašanjih, kakršna nam je zastavljal, v komentarjih naših seminarskih izdelkov, v samoumevnosti, $s$ katero je od nas veliko pričakoval, tako glede znanja kot glede odnosa do študija. Takšno samoumevnost je nemogoče, pa tudi absurdno normirati: v svetu hipernormiranih študijskih programov bržčas deluje kot tujek, kot neupravičeno obremenjevanje, vendar je v resnici nekaj povsem drugega: izraz velikega zaupanja in spoštovanja do študenta. Sam sicer s študijskimi obveznostmi nikoli nisem imel težav in sem počel poleg tega še druge stvari, je pa to zahtevalo veliko, celo zelo veliko dela. Ena najpomembnejših spodbud za prizadevnost je bilo prav profesorjevo visoko pričakovanje od nas, ki je zavezovalo veliko bolj kot formalne študijske norme; občutil bi celo nekakšen sram pred sabo, če ne bi pokazal znanja, ki ga je spoštljivo predpostavljal pri meni. Nerad govorim v prvi osebi množine, ko gre za izkušnje, a mislim, da ne bi bilo zelo narobe, če bi tu uporabil to slovnično obliko. Facit takšne zahtevnosti pa je bil spoštovanje do »naše stvari«, filologije: do jezika, do literature, do kulture in do tistega, zaradi česar vse to je: do življenja. Živahna, dinamična predavanja nikoli niso banalizirala snovi, da bi jo naredila življenjsko, kot počnejo mnogi, ampak so, nasprotno opozarjala na to, da življenje v bistvu ni banalno; da so tudi velika dela besedne umetnosti del naše življenjske resničnosti. Ko motriš svoje mere ob razsežnostih zgodovine in ob velikih dosežkih davnih dob, je to učinkovito zdravilo zoper hybris; če pa te takšna primerjava ne potre in ne poniža, temveč ti budi hvaležno veselje, da lahko vse to poznaš in na neki način imaš, je to humanizem, kakršen veje iz osebnosti profesorja Gantarja. Vsaj zase lahko rečem, da ga zaznavam tako.

Seveda je bilo osvajanje teh spoznanj in okušanje humanističnega duha skozi seminarsko dogajanje včasih tudi pitoreskno. Tedaj se pri uvodu v 
klasično filologijo nismo kaj veliko ukvarjali s tehniko citiranja, zato smo se morali pri oblikovanju bibliografije nekako znajti sami. In tako sem v naivni vnemi filološkega adepta v svoji prvi latinski seminarski nalogi (takrat so se še tipkale na pisalni stroj) pri vsaki enoti v seznamu literature vpisal čim več podatkov. »Hm, « se je namuznil profesor, »kako pa to, da omenjate celo Boulevard Saint-Germain? Imate mogoče tako nepozabno lepe spomine na dni, ki ste jih preživeli v Parizu? « Ob tem so se namuznili tudi starejši kolegi (kako se ne bi!), jaz pa sem si za vse čase zapomnil, da ima bibliografska enota štiri sestavne dele - tako zelo, da se še danes težko in ne brez odpora privajam na nova pravila. V moji zadnji seminarski nalogi, napisani v latinščini, je profesor našel tri napake. Mislil sem, da to ni slab dosežek, saj je bila naloga razmeroma obsežna, tema pa ne najpreprostejša, Horacijeva poezija, in to pri evropsko priznanem interpretu tega pesnika ... Toda ne: »Takšne napake - to je greh zoper Svetega Duha!« je vzrojil profesor. Moram reči, da je bila to ena bolj notranjedramatičnih ur mojega študija, od nje pa mi je ostalo, da tiste napake v zvezi s števniki najbrž ne bi ponovil niti opolnoči, kot se reče. A v takšnem pedagoškem slogu ni bilo sledu pikrosti, temveč je iz njega dihal žar zavzetosti za »literarno stvar« in duhovitost, ki sodi k takim rečem. V časih do zadnje potankosti normiranih didaktičnih modelov in vsakršne korektnosti tak slog kajpak izginja, kot še marsikaj, kar je intelektualno iskrivo in življenjsko.

Bila je ena prvih ur rimske književnosti, ne vem več ali so bila izbrana poglavja ali metrika; profesor je govoril o razliki med metrumom in ritmom. Našteval je bolj ali manj znane, nazorne primere »merjenega časa«, ki je človeški izum, in prešel k ritmu, ki je tudi naravni pojav, omenil razne ritmične pojave iz biološkega sveta, izmenjavo letnih časov, potem pa je nenadoma prekrižal roke na hrbtu, se zagledal skozi okno in z nekakšno zamišljenostjo dodal: »Ritem lahko odkrivate tudi, če prisluškujete bitju srca svoje mlajše sestre ...«. Tako popolnoma nekovencionalno, odtrgano od klišejev ... Bil je samo hipni intermezzo, a vendar trenutek, ko smo iz teorije metrike prestopili v območje poezije, zaradi katere smo nazadnje vsi skupaj tudi bili tam ...

Posebej navdihujoča lastnost je profesorjeva osebna skromnost. Neki moj vrstnik, literarni zgodovinar, je nekoč v popoldanskem času prišel na naš oddelek pogledat, če je čisto slučajno knjižnica odprta. Pred vrati je srečal profesorja Gantarja, ki je bil tedaj že v pokoju; ko mu je razložil, zakaj je tam, se mu je profesor opravičil, da mu on žal ne more izposoditi knjige, ker se je sedaj pač bibliotekarska procedura spremenila, sicer pa seveda to ne bi bil noben problem. Mislim, da je bil v tistem času podpredsednik SAZU.

Sicer pa je name najbolj vplivalo dvoje: neverjetno znanje in natančnost. Profesorjevo znanje, tako jezikovno kot zgodovinsko, je name v nekem obdobju imelo frustrirajoč učinek: bilo je nedosegljiv cilj, ki mi je dajal predvsem občutek lastne nezadostnosti. Najbolj zanimivo je, da profesor sploh ni nastopal tako, kot da bi hotel zbujati v študentu kaj podobnega; svojega znanja 
prav nikoli ni razkazoval, in to je delovalo name še huje: to znanje je pač bilo tu, mirno in nepretenciozno je obstajalo in skozi seminarske komentarje in pripombe in seveda skozi predavanja se ga je vsakdo lahko navzel po meri svojega zanimanja in prizadevnosti. Prav ta nevsiljivost, "normalnost « tolikšnega vedenja je bila najbolj nenavadna. Seveda nam je predstavljal mednarodna obzorja klasične filologije, vodilne edicije, publikacije, osebnosti iz preteklosti in sedanjosti, jasno, saj je to vendar sestavni del poklica akademskega učitelja; a prav zares se ne spominjam, da bi kadarkoli govoril o svoji mednarodni karieri, o množici odmevnih objav in članstev v prestižnih akademijah (kot so Accademia Properziana v Assisiju, Academia Latinitati fovendae, pa SAZU in Evropska akademija znanosti $v$ Salzburgu). Tudi svoje prevode je komaj kdaj omenjal, kaj šele da bi jih posebej izpostavljal. O tem so nam govorili drugi, njegovi kolegi, njegovi bralci, občudovalci. Mogoče je to samo moja izkušnja, mogoče sem kaj pozabil, a ne verjamem: če bi bilo zelo drugače, bi si to zapomnil. Napad na šesta mestna vrata v Ajshilovi Sedmerici proti Tebam vodi videc Amfiaraj, ki ga »je ptič usode porinil med krivičnike« (vv. 597-598, v prevodu Alojza Rebule); medtem ko junaštvo slednjih oznanjajo kričave poslikave njihovih ščitov, pa je vidčev ščit brez podobe, kajti »on noče zgledati, on hoče biti junak« (v. 592).

Mogoče smo tako dobili največ: brez velike didaktične in epistemološke teorije, preprosto $\mathrm{z}$ resnim in tudi ambicioznim reševanjem konkretnih tekstualnih problemov, ki nas je vodilo $\mathrm{v}$ razne smeri in predvsem pod površino ozko razumljene filologije, kmalu tudi do temeljnih vprašanj literature, njenih funkcij, estetike, etike, njenega smisla. A ker smo prišli do njih po takšni poti, ta vprašanja za nas niso bila nekakšne okamenele forme $\mathrm{v}$ jalovi deželi abstrakcije, ampak "naravno« ozadje čisto realnih, tako rekoč otipljivih, vsakdanjih filoloških zadev. Z leti sem začel v osrčju Gantarjevega odnosa do literature (v najširšem pomenu vsega zapisanega, ki ga ima ta beseda tradicionalno v klasični filologiji) prepoznavati iskreni sokratovski »vem-da-nič-ne vem«, ki je dal čisto nov smisel njegovemu občasnemu priporočilu: »Ostanite na trdnih tleh filološke znanosti.« Počasi sem dojemal, da s tem ne sugerira omejevanja in poenostavljanja resničnosti, ampak samoomejevanje in spoštovanje njene kompleksnosti. Tako razumljena »trdna tla« človeku, predvsem mlademu, pomagajo, da ne zdrsne preveč zlahka $\mathrm{v}$ ekscese raznih literarnih, kulturnih in političnih ideologij in da okrepi odpornost zoper njihov sirenski magnetizem. $\mathrm{K}$ realističnemu odnosu pa je prispevalo še nekaj: zanesljivo občutje, da realnosti ni mogoče zamejiti z instrumentalnim umom. Pietetni čut za misterijske razsežnosti resničnosti, na obalah katere skozi zgodovino vznikajo religijske institucije, za prostorja, iz katerih je nekoč prihajala poezija ... Iz tega izvira nekakšen pravi občutek za velikosti stvari in za lastno mero, ki ga je nemogoče konceptualno fiksirati, ki pa kljub temu je. Métron kaì mystérion je starodavna spoznavna in etična diada iz soodvisnih členov. Če bi moral na najkrajši način 
povzeti profesorjeve ágrapha dógmata, nenapisani nauk, bi uporabil prav to sintagmo. Seveda pa je to samo metafora: saj ni šlo za nikakršno doktrino, ampak preprosto za odnos do filologije, do književnosti, zgodovine in kulture, kakor se je izražal v celovitem načinu profesorskega dela in ki ne bi mogel biti tako prepričljiv, če ne bi izraščal iz življenjske izkušnje. Podobno mislim o njegovih imenitnih predavanjih - redkokoga sem v življenju poslušal z več zanimanja, pa tudi z več užitka: profesor je zbujal občutek, da ga snov zares zanima, da se ga dotika »od znotraj«, da ima nekakšno življenjsko vrednost - zato nikoli ni bila samo študijska snov, ampak je imela okus po resničnosti.

In potem njegova natančnost! Še danes se mi včasih zaustavijo prsti na tipkovnici: »Kaj natanko ste mislili s tem? « zaslišim profesorja. »Ja, res, tole pa ni jasno!« pomislim potem. »Sem sploh povedal, kar hočem? Kako pa bi pa to razumel, če bi prihajal z druge strani besedila, če ne bi bil pisec, ampak bralec? Ne, to ni to ...« In poskusim preformulirati, najti natančnejši, jasnejši, bolj slovenski izraz, še enkrat premisliti, kako natanko sploh je z zadevo, s katero se trudim, se napotiti bliže proti bralcu ... V študentskih letih teh zahtev po natančnosti nisem vedno sprejemal z notranjim navdušenjem, najbrž so se mi kdaj zdele tudi pikolovstvo. Toda natančnost gotovo sodi med kardinalne kreposti klasične filologije, najbrž pa tudi vsakega dobrega sloga. Seveda ne trdim, da je moj slog dober, zagotovo pa vem, da bi bil slabši brez tistih »sitnih« seminarskih vprašanj, ki so se mi zalezla pod kožo in postala moj lastni kriterij. Za nekatere stvari je pač potreben čas. »Šele ko boste starejši, boste opazili, kaj to pomeni, « je dejal Jakob Bernays Ulrichu Wilamowitz-Moellendorfu, ko mu je ta leta 1867, kot sam pravi, v maniri rumenokljunca govoril proti Evripidu; in nato mu je prebral začetek druge zborove pesmi iz Blaznečega Herakla (vv. 637-700). Koliko bolj to o dozorevanju in razumevanju velja za navadne smrtnike!

Glas, ki se mi je, malce emfatično rečeno, naselil v kosteh, pa nikakor ni glas nepremagljive profesorske avtoritete, ampak opomin: resnični avtoriteti sta stvar, o kateri govoriš, in bralstvo, ki bi mu jo rad približal, po tem se gre ravnati. Spominjam se, kako je profesor nekoč, ko je nekdo na seminarju branil svojo trditev s sklicevanjem na neko znano ime, napisal na tablo: »moč argumenta « in »argument moči« in med obe besedni zvezi postavil prečrtan enačaj. Kako antiavtoritarno! Kako subverzivno pravzprav! In opogumljajoče.

Tisto, kar pa me prav posebej fascinira je profesorjeva intelektualna prisebnost. Kaj hočem reči s tem? Nihče ne ve vsega, zato sogovorniki v intelektualnih debatah od seminarskih predavalnic do prestižnih simpozijev pogosto poskušajo uveljaviti svojo perspektivo, pomen svojega vedenja in metodologije in omejiti razpravo na področje, kjer so suvereni. Pri tem framingu neredko ignorirajo sogovornikovo stališče, bagatelizirajo njegove poglede, ga zasujejo $\mathrm{z}$ bolj ali manj pomembnimi referencami, ali pa ga $\mathrm{z}$ gosto retoriko »prevpijejo« in zmedejo. Pri Kajetanu Gantarju imajo take taktike bolj malo možnosti za 
uspeh. Seveda ga je zaradi njegovega ugleda vsaj načeloma teže ignorirati, širina vedenja pa oži manevrski prostor polemične manipulacije. A bolj pomembno se mi zdi dvoje: prvič, navadno diskutantu prisluhne s pristno radovodenostjo, kakršne nisem pogosto srečal, in ga že s tem vplete v dejanski dialog in ga iz zelotskega prepričevalca spremeni v živahnega sogovornika. Drugič pa je njegov premislek kulture in zgodovine tako temeljit, da mu omogoča mirno in prisebno držo tudi ob soočanju s hudimi teoretičnimi in metodološkimi novitetami: nekatera njegova prepričanja so namreč dovolj tehtna in človeško relevantna, da onus probandi ni na njih, temveč na novatorski kritiki.

Ta prisebnost se izrazito kaže v etičnih zadevah. Generacija profesorja Gantarja je ena tistih, ki so doživele zgodovinsko katastrofo zaradi vojne in totalitarnih sistemov, ki so tako radikalno posegli v njihovo življenje in amputirali velik del slovenskega prebivalstva in kulturne tradicije. Prav poseben vidik te katastrofe je, da v svojem bistvu ni bila reflektirana; morda je bila do neke mere popisana, reflektirana pa ni bila. Niti znamenita fraza iz Viscontijevega filma Il Gattopardo »Če hočemo, da vse ostane, kot je, se mora vse spremeniti, « ne izrazi ustrezno nenavadnega stanja, ki je nastalo po prehodu iz totalitarizma v demokracijo. Zdaj se namreč zdi, kot da zgodovina obenem obstaja in ne obstaja - in v takšnem stanju je tudi etična neprisebnost postala izredno pogost, če ne skorajda normalen kulturni pojav. Vendar to ni primer Kajetana Gantarja: njegov etični in zgodovinski kompas se ni zmedel in kot ni klonil pod nasiljem zgodovine, je imun tudi na nenavadno vrednotno konfuznost sodobnosti. Ni mu treba skrivati, kaj je in kje stoji. Litotično rečeno: v ne ravno ugodnih okoliščinah je postal prvo ime slovenske klasične filologije in ne nepomebna referenca $v$ mednarodnih krogih. S svojo prevajalsko umetnostjo vtiskuje nespregledljiv pečat slovenski literaturi in če nikoli v zgodovini ni nastajalo toliko slovenskih prevodov antične, srednjeveške in renesančne literature kot $\mathrm{v}$ nekaj zadnjih desetletjih, ima pri tem brez dvoma velik delež zaslug, neposredno in posredno, tudi kot učitelj mlajših generacij.

»Vmes tvoja tožna je človeška slika," se končuje pesem Belo in črno, s katero smo začeli. Tako je videl notranjo podobo Božidarja Jakca pesnik Alojz Gradnik. Podoba profesorja Kajetana Gantarja pa ni tožna: portret, ki bi ga prikazoval tako, ne bi bil prepoznaven. Zgrešil bi njegov globoko človeški realistični optimizem in njegov živahni pogled, ki je sicer usmerjen v davnino, a $\mathrm{v}$ resnici ves čas gleda $\mathrm{v}$ prihodnost.

Brane Senegačnik, Univerza v Ljubljani, Filozofska fakulteta; branko.senegacnik@ff.uni-lj.si 


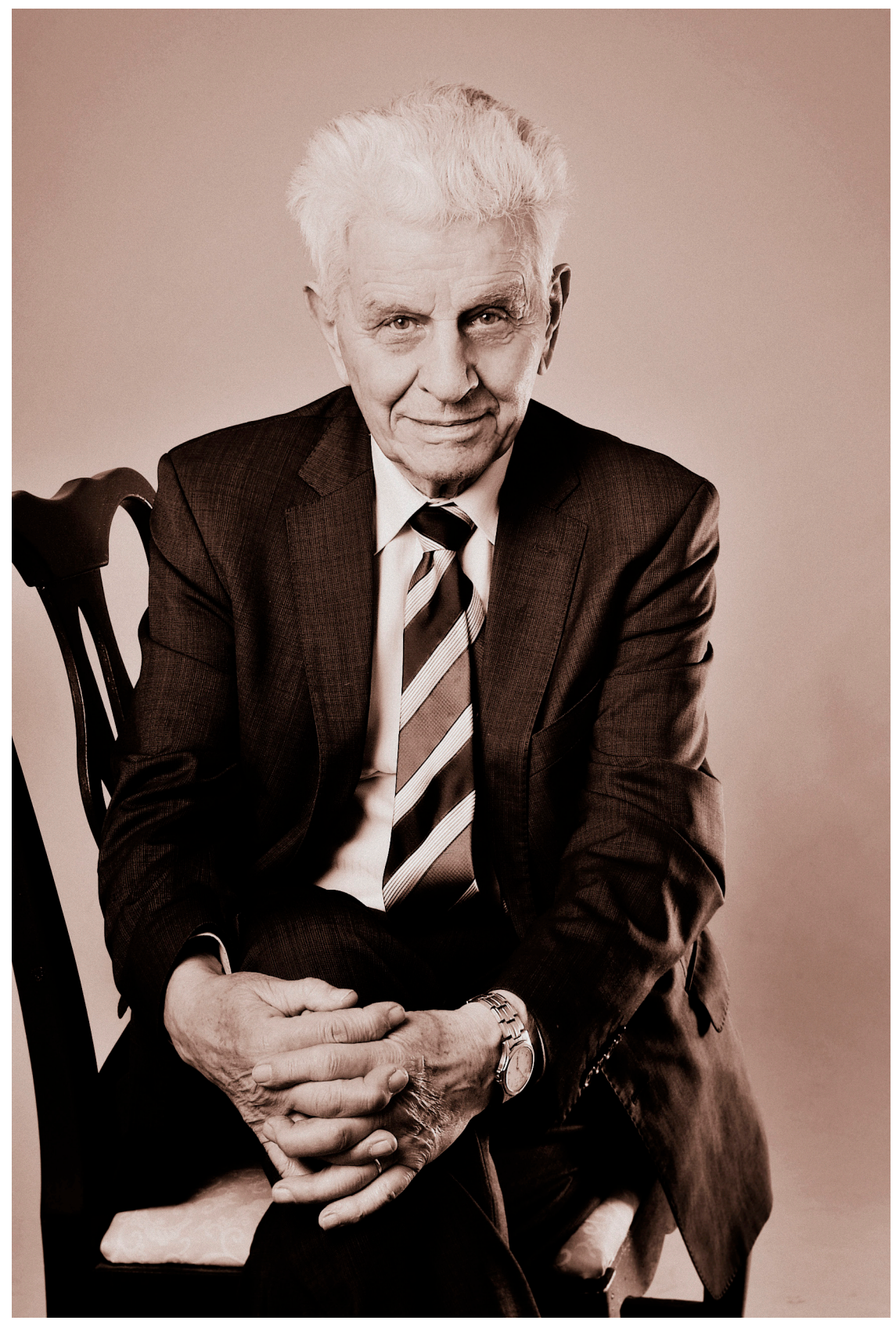

dr. Kajetan Gantar 